\title{
EVALUATING THE DISCONTINUED TRADITIONS OF MALAY WOOD CARVINGS IN MALAYSIA: A FAILURE TO DEVELOP THE DISCOURSE ON MODERN AND POST MODERN ORNAMENTATION IN ARCHITECTURAL WORKS
}

\author{
${ }^{1}$ Nangkula Utaberta and ${ }^{2}$ Mohamad Tajuddin Haji Mohamad Rasdi \\ ${ }^{1}$ Department of Architecture, Faculty of Design and Architecture, \\ Universiti Putra Malaysia, Serdang, Selangor, Malaysia \\ ${ }^{2}$ Department of Architecture, Faculty of Built Environment, \\ Universiti Teknologi Malaysia, Skudai Johor, Malaysia
}

Received 2013-10-16; Revised 2014-03-14; Accepted 2014-04-19

\begin{abstract}
The main intention of this study is to contribute some thoughts on why the tradition of wood carvings in traditional Malay architecture was discontinued at the rise of modern and post-modern architectural works in Malaysia. Although the tradition of wood carvings more or less came to a stop in public architectural works with the development of colonial architecture, this study seeks to clarify the modernistic and post-modern arguments on the problem or issues of ornamentation. Although modernism mainly or seemingly rejected the use of ornaments, there was still a strong strand of its development in the architecture of Frank Lloyd Wright. The western post-modernist architects such as Michael Graves and Charles Jencks went on to develop a discourse on ornamentation under the area of architectural meaning and linguistics. It is expected that this critic paper can segragate and analyse issues and problems of Malay wood carvings and start a further discussion on the development of this traditional heritage which can contribute and reconstruct a better framework for the Architectural Identity of Malaysia.
\end{abstract}

Keywords: Malay Wood Carving, Modern Architecture, Post-Modern Architecture

\section{INTRODUCTION}

The paper is divided into three main parts. The first part presents a brief evolution of thoughts concerning the relationship between ornament and architecture as we have understood them in the western context. We hope to show that the idea of ornament went through important changes in form, motif, materials and philosophy. The second part of this study presents a look at some of the approaches of architecture towards defining a Malaysian identity. We hope to show the lack of ornament and if there was any done, it was at a superficial level. The final part of this study presents my own personal thoughts as to my position on ornament and how it might be reinterpreted into the modern context (Hassanpour et al., 2012). The 'semangatkayu' of wood carvings comes directly under the general considerations of ornament in architecture. It is hoped that this study can spark an attempt to put back the question of architectural ornamentation as a valid and professional discourse so that we could create a more meaningful architecture for our society in this part of the world.

\section{THE ISSUE OF ORNAMENTATION IN WESTERN ARCHITECTURE}

We would like to begin the discussion on ornamentation in architecture by expounding what we

Corresponding Author: Nangkula Utaberta, Department of Architecture, Faculty of Design and Architecture,

Universiti Putra Malaysia, Serdang, Selangor, Malaysia 
know of the western architectural context. There are three reasons why we have chosen this beginning. Firstly, my architectural training is from the West and so is most of the architectural fraternity in the education or practice line in this country. Secondly, there is quite an abundance of literature on this subject matter as oppose to those found in our part of the world. Thirdly, the issue of ornament in architecture is directly related to the idea of political governance in a western conception of democracy and constitution. We will suggest how much of the discourse in architecture and ornament directly relates to the ideas of political governance.

\subsection{The Western Vernacular Tradition of Ornament and Architecture}

We suspect strongly that there was no strong issue of ornamentation in most traditional societies for various reasons. Homogenous societies that believe in a theocentric conception of community have well understood rituals and codes of behaviors with the corresponding symbols in its physical manifestation. Thus statues, figures, carvings of floral, cosmic or animal motifs are part and parcel of a coded language well understood by all. It was accepted that the temple or the palace or the residence of the tribal leaders would show much carvings and ornamentation for the project a special social and spiritual message. The existence of ornament as part and parcel of a complete architecture was accepted without much moralistic argument. There was no question of whether ornament is a non-structural element and therefore no concern of its moral existence. The Greeks, Romans (sample building shown at Fig. 1) and Gothic architects (sample building shown at Fig. 2) conceived ornaments for reasons of sending spiritual and ritualistic messages in its many forms. In the architectural treatises of Vitruvius, there were descriptions of ornaments in a-matter-of-fact tone as in his description of the structural proportions of columns and arches. The feudalistic and hierarchic nature of life which revolves around the kings, aristocrats and priests may have aided in the total acceptance of ornament as part of a religious and stately symbolic message. Thus in the vernacular tradition of the early Western architects there was simply no issue of ornamentation as it is part and parcel of architecture and life.

\subsection{The Issue of Ornament and Architecture in the Age of the Renaissance}

The Renaissance began a systematic imitation and adoption of Classical Greco-Roman architecture (sample building shown at Fig. 2). The period saw the birth of a new patron of the arts aside the royals, aristocrats and clerics. The rich merchant and middle class began to crave for symbols of status and ornament in architectural work found new meanings as status symbols other than the religious or the official creed. The 18th century ushered in the new super powers of the French, British and Spanish which began its conquest and influence of the known world. The Battle of Styles erupted in Britain, France, Germany and later on in the new world of the Americas. The middle class sought many books on the proper architectural languages of Greek and Roman architectural vocabulary. Andrea Palladio's book on the four Books of architecture inspired many architects such as Christopher Wren and Inigo Jones to experiment with the various eclectic mixtures of Roman, Greek and sometimes even Egyptian architecture. The concern then was whichever architect adopted the truest forms and proportions of the ancient classical architecture, his work would be considered the best. Thus began much works of measuring and drawing of the ancient ruins of Western Europe. The political hierarchy was still feudalistic with an addition of a new aristocracy, that is, the rich merchant class. At this time the moral question of ornament is about which carvings was most appropriate in the sense of its authentic origins.

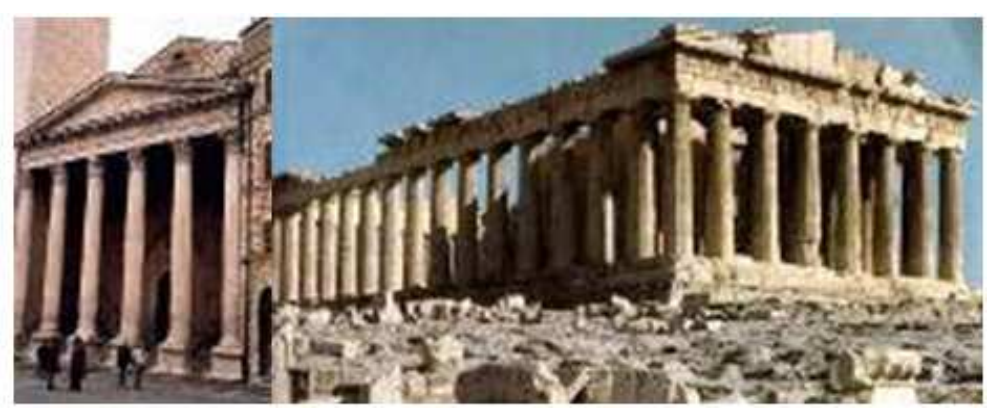

Fig. 1. Roman and Greek Temple (Parthenon-448 BC) 

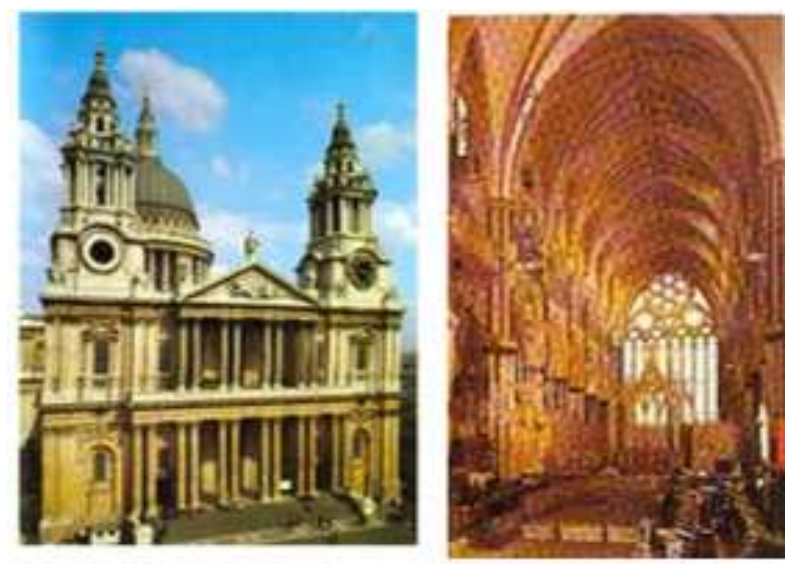

Fig. 2. Renaissance (St Paul Cathedral-1675) and Gothic Building (Lincoln Cathedral-1256)

\subsection{The Issue of Ornament and Architecture in the Age of Enlightenment}

The 19th century was a period of great questioning of politics, religion and the arts. This new debate was fueled by the birth of rationalism and scientific thoughts. Centuries of religious dogma was replaced by strict Christian doctrines administered by the all powerful clergy that stifled philosophical musings as well as rational quests for the alternative explanation of cosmic and social truths. The likes of Copernicus, Galileo and Darwin pierced at the very heart of Christian dogma thus unleashing for the first time thoughts on all issues of life including that of ornament and architecture. Laugier questioned the very existence of ornamentation and disclosed his treatise on a rationalistic approach of utilitarian and primitive architecture. Augustus Welby Pugin (sample building shown at Fig. 3) wrote passionately of ensuring the utilitarian aspect of ornament by describing the gargoyles sitting on the flying buttresses of Gothic Cathedrals as counterweights against the thrust of the masonry arches:

"Nothing must be included which was not for "convenience, construction or propriety." The building must honestly express its function and materials. Ornament should consist of "the essential of the building." The structure must be expressed not covered up with the arbitrary or superfluous decoration."

Pugin (1977), True Principles of Pointed or Christian Architecture p.1

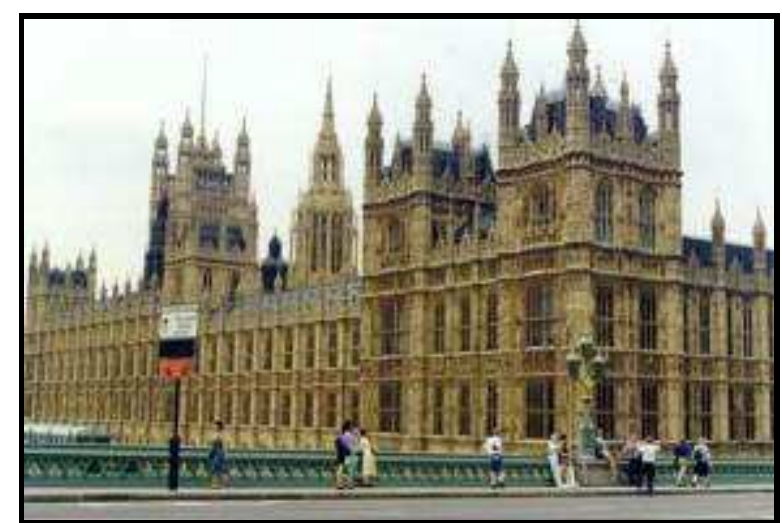

Fig. 3. British Parliament Building, Augustus Pugin

John Ruskin went to great lengths to expound on his idea of proper architecture in his Stones of Venice and the Seven Lamps of Architecture by building up a discourse on the proper placement and motifs of ornament. Ettine Boullee created architectural masterpieces on paper to glorify libraries and Issac Newton as opposed to palaces and churches with huge edifices adorned with a single layer of ornament gracing a pure platonic form. The master architect Claude Nicholas Ledoux designed buildings with clear pristine elements devoid of any superfluous carvings or ornaments. Thus, it can be seen that there were several moral questions of ornament and architecture. Firstly, there was the drastic question of whether its existence was necessary at all. This had a small following. The second moral question is on the utilitarian aspect to justify the existence of ornament as in the case of Pugin and the Gothic style or language. Thirdly was the question of its appropriate expression and placement as in the thoughts of John Ruskin.

\subsection{The Different Strands of Early Modernism on the Issue of Ornamentation}

The late 19th century and the early twentieth century saw several strands of architectural approaches that redefines the use of ornament. The Art and Craft movement that took Britain was lead by William Morris and John Ruskin (sample product shown at Fig. 4). The two intellectuals were wary of copying classical ornament and architectural vocabulary but instead used their own motifs and developed designs for wall papers, furniture's and utensils (Ruskin 1925). This idea of redefining the motifs were expressed strongly in another movement

AJEAS 
called Art Nouveau that saw the use of iron as the new expressive materials. In Victor Horta's hand, columns merge into trusses and beams in a floral configuration that supports the structural moment connections (Fig. 4). The union between ornament and structure as echoed in Pugin's criticism and admiration of Gothic architecture came to a head with the designs of Antonio Gaudi's Cassa Battlo apartments (Fig. 5). Here the use of reinforced concrete was stretched to its structural perfection and form within the metaphorical interpretations of dragons and mythical creatures.

In the United States of America, whilst the Chicago Tribune Tower by Raymond Hood ended the modernistic romance with Gothic architecture, the master designer, Louis Henry Sullivan (Fig. 5) and his soon-to-be famous student, Frank Lloyd Wright, showed the world what modernism could achieve in the new materials of steel and reinforced concrete. In his Wainwright Building, Sullivan showed how the proper use of ornament can be applied to grace a tall structure. In his bank designs, huge arches defining the entrance and wearing an upgraded classical garb was inscribed with floral motifs specially designed by the 'Leiber Meister' himself (Fig. 5). However, proponents of more 'functionalist' strand as that of Henry Hobson Richardson rejected ornamentation and substituted the strength and monumentality of a new interpretation of Romanesque vocabulary. The Trinity Church and his library designs attest to the power of expressing undressed stone and cut masonry in an architectural language that would soon echo in Le Corbusier's Monastery La Tourette and the chapel at Ronchamp almost a century later.

We consider Frank Lloyd Wright (sample building shown at Fig. 6) as the master builder who left a strong legacy of modernism within a humanistic vocabulary of people architecture and as the last sculptor-architect model. Untrained in the formal aesthetic of Classicism and university education, Wright presented American society with a Prairie Architecture that was both unique and expressive. He later termed this architecture as Organic:

"Architecture organic, perhaps because firstly deeply concerned with the integrity of innate structure, first grasped the demand of our modern American life for higher spiritual order." Wright (1958), the Living City, p. 92
"The real body of our universe is spiritualitiesthe real body of the real life we live. From the waist up we're spiritual at least. Our true humanity begins from the belt up, doesn't it? Therein comes the difference between the animal and the man. Man is chiefly animal until he makes something of himself in the life of the spirit so that he becomes spiritually inspiredspiritually aware. Until then he is not creative. He can't be".

Wright, Frank Lloyd, Truth against the World, p. 270

As with Richardson, his building materials possessed an expressive and humble monumentality amidst his platonic forms of cubes, cylinders and spheres. He developed a new ornamentation system that could be mass produced and prefabricated but which had the geometric lines of the machine. The Barnsdal Residence and the Midway Gardens restaurant showed Wright to be the complete designer with sculptures, reliefs, furnitures, fixtures and tapestry designs. Wright proposes the total integration of ornament with not only the structure but with the whole experience of space and architecture.
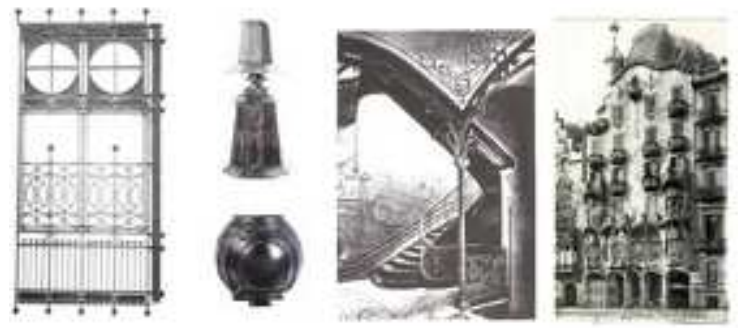

Fig. 4. Some art and craft furniture, tassel house-victor horta, casa battlo-antonio gaudi

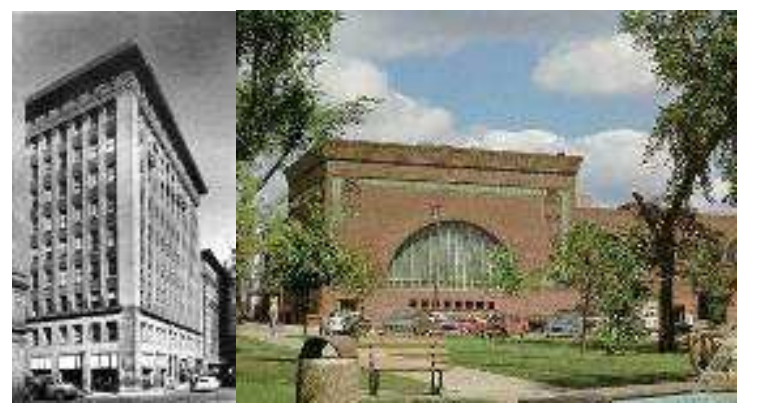

Fig. 5. Wainwright building and national farmers bank by Louis Sullivan 


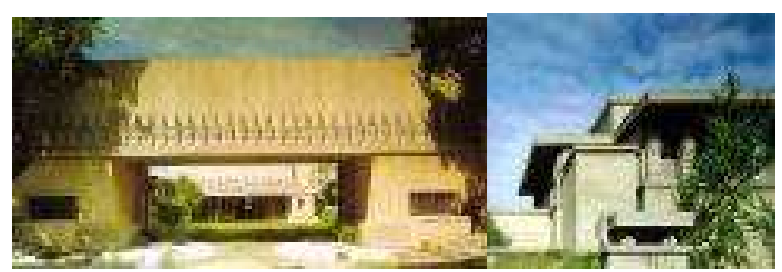

Fig. 6. Barnsdall House-1921, Unity Temple-1913

Herman Muthesius saw the genius of Wright and helped staged the first exhibition of Wright's work in Germany. The apprentices of Peter Behrens came to this exhibition and they were soon designing within the same spirit of mass, materials and volumes but minus the ornamental system. The young apprentices by the name of Ludwig Mies van der Rohe, Le Corbusier and Walter Gropius went on to be master designers in their own right by expressing structure and form but abandoning the grammar of ornament. Le Corbusier, in his Vers une Architecture condemns ornament in his attack of 'styles as in the following excerpt:

\footnotetext{
"Great Epoch has begun.

There exist a new spirit.

There exist a mass of work conceived in the new spirit; it is to be meet with particularly in industrial production.

Architecture is stifled by custom.

The "styles" are a lie.

Style is a unity of Principle animating all the work of an epoch, the result of a state of mind which has its own special character".

Corbusier (1962). VersUne Architecture, p. 19
}

The influence of Adolf' Loos's dictum of 'ornament is crime' still echoed strongly in the young modernists of that time that eventually led to a whole world rejecting this grammar of ornament.

"Children are amoral and-by our standards-so are Papuans. If a Papuan slaughters an enemy and eats him, that doesn't make him a criminal. But if a modern man kills someone and eats him, he must be either a criminal or a degenerate. The Papuans tattoo themselves, decorate their boats, their oars, everything they can get their hands on. But a modern man who tattoos himself is either a criminal or a degenerate. Why, there are prisons where eighty percent of the convicts are tattooed and tattooed men who are not in a prison are either latent criminals or degenerate aristocrats. When a tattooed man dies at liberty, it simply means that he hasn't had time to commit his crime... what is natural to children and Papuan savages is a symptom of degeneration in modern man. I have therefore evolved the following maxim and pronounce it to the world: The evolution of culture marches with the elimination of ornament from useful objects (Adolf Loos). Curtis (1996), Modern Architecture since 1900, p.36.

In many ways, the Werkbund (Fig. 7) which was set up by Muthesius was party to this rejection of ornament which was expressed in the works of Wright and the Art and Craft movement. The idea of functionalism as a determining element of architecture took hold of not only Germany but eventually the whole world with the advent of the International Style.

Thus, in this most creative period of architecture, ornament was seen in five different perspectives. The first perspective is that of the moral issue of propriety. The second perspective is that motifs and materials should be redefined in favor of a more vernacular and down to earth expression. The third perspective saw the idea of machine industrialization and geometricisation of ornament in new forms. The fourth perspective is the marriage between ornament and structure. The final perspective is the most enduring and that called for the total elimination of ornament from the vocabulary of functionalist designs.

\subsection{The Consolidation of the International Style and the Total Elimination of Ornament}

The International Style was simply a theme created by Phillip Johnson and Henry Russel Hitchcock during an exhibition of European architect's work in mid $20^{\text {th }}$ century. The exhibition was mostly responsible for propelling the modernist vocabulary of utilitarian steel structural cages with curtain walling of glass and aluminium. The only strand of ornamentation was that by Wright and even then the great master himself had succumbed to the mystic and grandeur of structural forms. After what seemed as a brief decade of functionalist cages, architects such as Eero Saarinen began to explore structural forms that had some kind of abstracted metaphorical meanings. The Yale Hockey Rink, the TWA Terminal and the New York Airport Terminal showed the forbidden experiments in meanings (Fig. 8). This was quite a departure from the modernists' 
dictum of the building as pure shelter with structure as a means of expressing the spirit of technology and of economic construction. Although the 1950's and 1960's high rises in the USA were mainly steel cages purportedly created from pure functional necessity, critics were quick to point out that the steel mullions 'pasted' on shear walls of buildings such as the famed Seagram Tower (Fig. 8) could be construed as 'ornament' as they did not perform and constructional or structural function! Thus, in this period, there was still the prevailing strand of not putting any ornament as it was traditionally understood. However there was a strand of approach that saw an attempt at giving meanings to buildings by the expression of structural form. Can this be construed as the new idea of 'ornamentation'?

\subsection{Early Criticism of Modernism on Meaning and Form in Architecture}

One of the first criticisms against the bland modernist vocabulary was by totalitarian regimes such as those of Adolf Hitler and Benitto Mussolini (Fig. 9). Both leaders saw that the salvation of their two countries lie in building an empire psyche for the society and to resort to architecture as the expression of historical continuity from the Roman grandeur of the past. Since modern architecture rejected historical references because of their attacks on ornament, Hitler accused the modern masters as communist sympathizers and drove them out to America.

Thus Hitler and Mussolini commissioned grand gestures in architecture at many times the scale of the Roman heritage. Great heroic sculptures stood against the city backdrops and huge columns with abstract capitals marched in unison fronting buildings and arcades. However, there was still no sign of the traditional ornamentation of relief and carvings but only abstract formal imitations of Roman heritage architecture.

The second wave of criticism were by those who saw the dangers of globalization in the form of the International style. Coupled with rising oil prices and the rise of politically independent states which were colonized by the west, these new architects saw that regionalism was a better way to produce good pieces of architecture. The vernacular tradition was sought for its lessons in material usage and energy efficient solutions. Much of this attempt culminated in the seminal works of the master builder Hassan Fathy (Fig. 10) who studied adobe brickwork and built townships out of mud to solve the socio-cultural and economic problems of the middle east peoples.
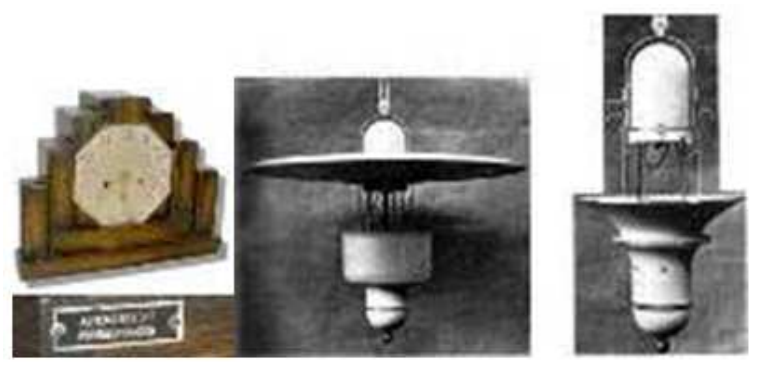

Fig. 7. Some Werkbund's product

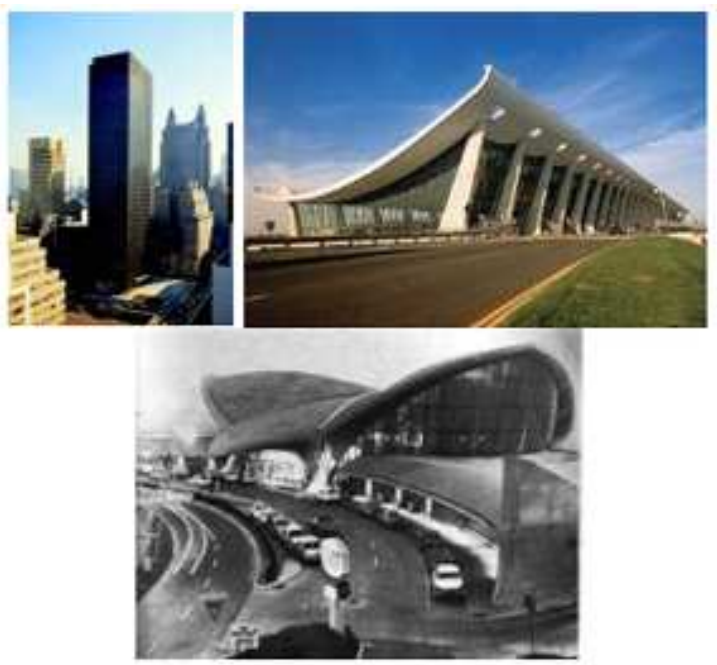

Fig. 8. Seagram Building-Mies van der Rohe, Dulles Airport and TWA Terminal-Eero Saarinen

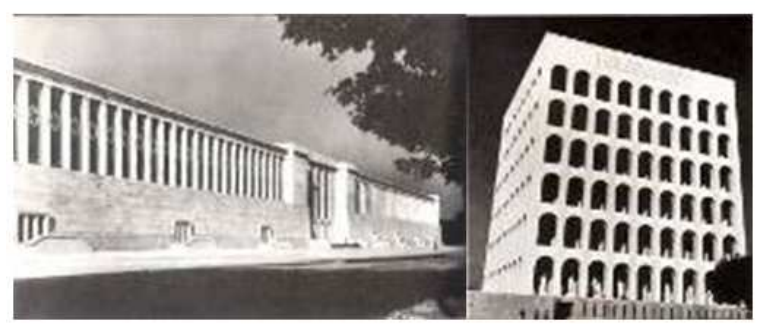

Fig. 9. Hitler and Mussolini's building

A final strand of critics came from the students of the great modernist masters such as Michael Graves (Fig. 11 and 12) and Robert Venturi who went on to develop meaningful architecture through the introduction of an elitist architectural language of form, colours and elements. Almost a century went by before architecture was learning to speak again. I consider these attempts as the new ornamentation system although much of these elements were infused with columns, railings and wall planes. 


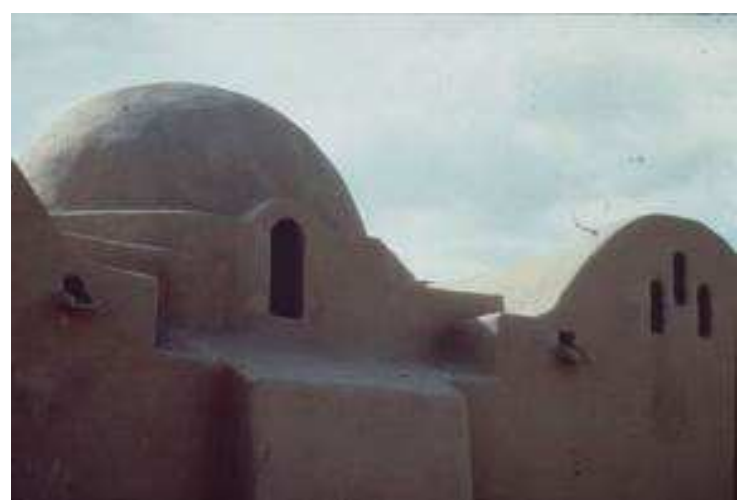

Fig. 10. Masjid New Gourna, Luxor Mesir-Hassan Fathy

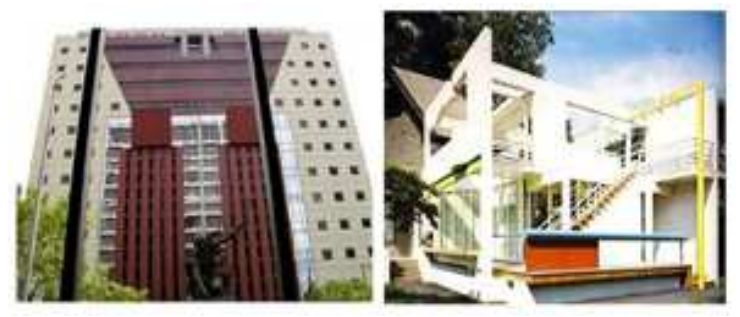

Fig. 11. Portland Building, Benacerraf House-Michael Graves

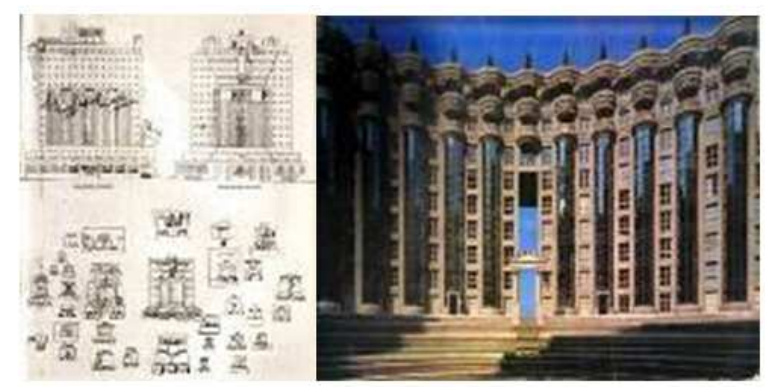

Fig. 12. Sketches of Michael Graves-Portland Building, "The Arch and the Theatre"-Richardo Bofill

\subsection{The Language of Post Modern Architecture and the New Idea of Ornamentation}

In the 1980's a revolution once again took place in the architectural world. Ornament was back. This time in its pure naked form, unconnected to structure of whatever functional purposes. The American Telephone and Telegraph Company by Phillip Johnson contained an unmistakable pediment with a baroque crown. Michael Graves went on to design the Portland Municipal Building complete with reinforced concrete garlands and statues. The garlands was a tool that contains messages of 'celebration' and 'importance' for a tight budget building charged with being the 'palace of Portland'. Michael Graves and Ricardo Bofill (Fig. 12) also introduced a new idea of considering architecture as a box full of meanings. In the Portland building by Graves and in the Taller Architectura Apartment by Boffil (Fig. 12), they both created signs of gateways and grandiose columns by using colored panels and glass. The modernist dictum that a column should be expressed structurally has now been totally shattered because both architects saw fit to communicate the idea of huge columns without them being necessarily structural. Thus, we consider that the idea of ornament in the Western discourse went from being a simple floral motif, to a structuralized form and integrated structure and finally as a sign for an understood architectural element.

Finally, the work of Jencks (1977) in his Thematic House brought ornament back to where it once began. In renovating his own house and as documented in his book 'Symbolic Architecture', Jencks (1985) laments the pluralism and emptiness of modern life that saw no more myths, legends and beliefs. Life in the modern age was as functional as architecture. There was no religion or superstition to glue society together in order for an artist to produce a meaningful form. Thus Jencks resorted to themes of the cosmos and the environment as the two last common 'belief system' of Westerners but he resorted to Greek mythology and a personal set of language to produce to him a more meaningful architecture that can be read by many of his own peers.

\section{DISCUSSION ON THE SEARCH FOR A MALAYSIAN ARCHITECTURAL IDENTITY}

Based on the previous discussion we can conclude that the search for a national identity seems to be a must for countries which have either newly become independent or with a leadership that stresses certain groups of race as 'better' than others. To most countries, this search is a high profile event as it has strong political implications (Tajuddin, 1999). Of all the arts and technology produced by man, architecture is the most conspicuous of them all. The search for a national identity is a most difficult endeavor and for a multicultural nation, the effort is even more so. To search for one's identity is also something of a peculiar nature since it implies that one has either lost the identity or does not have a clue as to who one is. In this section, we will 
attempt to classify the various approaches towards answering the problem of a national architectural identity without considering whether there was a conscious effort or not by the architects.

\subsection{Natural Architectural Identity}

A natural architectural identity can be defined as one which has what the modernist thinkers refer to as a 'spirit of the times' and what present post-modernist concerns of a 'spirit of the place'. A building is supposed to possess true identity if it responds religiously to the idea of both spirits. The idea of spirit of the times refers to a direct response of the users and builders to the available technology, the structural know how and the economic consideration of a particular time (Tajuddin, 2001). Thus, the Malay house with its long gable roof, timber post, beam and wall construction and small human labor is as true to its times as the mud construction of traditional Egyptian architecture and the arched masonry construction of the Romans. In the modern age, the only natural identity which can be found as relates to the spirit of contemporary technology is the stadium and bridge construction. Long span bridges of two kilometers tend to have the inverted catenaries arch shape of suspended high strength steel whilst stadium structures use the pneumatic, tent and reinforced concrete cantilevered shell. These structures are shaped in the manner that the structural system and the economies of construction dictate.

The idea of spirit of place refers to the direct response of the builders to climatic considerations, geographic make up of the land and the culture of a particular society. Thus the Malay house with its isolated mass, raised platform, generous serambi's or verandahs, full length windows with kerawang ventilation grilles and high roof form to ease the passage of air and shed off heavy rainfalls contrast strongly with those of temperate regions of heavy masonry walls with barrel vaults containing little openings to trap heat in and hold the snow at bay. The colonial and sino-eclectic heritage in Malaysia presents excellent examples of this type of natural identity. The sino-eclectic heritage brought with it the Chinese masonry construction in such buildings as the Kampung Hulu Mosque in Melaka (Fig. 13) and the long shop houses found in the same state. The colonial heritage presents two interesting building types which are the Palladian all masonry buildings and the reinterpretation of Malay timber buildings. In the colonial and sino-eclectic architectural heritage, innovations and adaptation to the climate were ingeniously developed in the high ceiling interiors, clerestory windows and the use of air-wells or internal courts. Masonry has a heat lag property that absorb heat during the day and slowly releases this stored energy at night. The colonial builders were aware of this phenomenon and thus experimented with the proportion of the interior space, placement and amount of fenestration area with also some ideas of placement and sizes of air-wells. The colonial heritage also provided Malaysia with their version of the Malay House with louvered verandah and walls to replace the ornate serambi ballustrade, the squat Palladian proportion to replace the high raised platforms and the hipped gable roof with ventilation openings. These buildings are identities in their own right since they represent the new Malaysian architectural entity with Western upbringing and the tools of modern technology. It is a fortunate thing that the government of the day recognizes the importance of these heritage buildings but it is most unfortunate that local architects do not appreciate their design solutions and opt for a more energy active architecture of air conditioning and electric lights.

\subsection{Forced Architectural Identity}

A forced architectural identity can be defined as that which is produced by clients for the users who have little choice in the matter. The best example that we can see in Malaysia is the modern housing estates (Tajuddin, 2003). The main characteristics of these housing estates have hardly changed in the four decades of its introduction. The estates are laid out in a grid-iron manner which suits cars better than its human occupants. The houses are of plastered masonry in-fill walls over a reinforced concrete structural frame. The common typology is the terraced or link houses with little fenestration and hipped-gable timber roofs of clay tiles. The other typology is the walk up tenement of the same construction materials and structure. Another characteristic of the link houses includes a car porch with back alleys as setbacks. On the one hand, this is the typical modern identity that litters the country but on the other hand, much of its architectural features negate the understanding of masonry construction in a tropical setting such as those of the colonial masonry heritage. The site lay out as well as the spatial planning of the buildings ignores much of the cultural lifestyles of the occupants. An obvious clue to this malady can be seen in the renovations that are usually done just as soon as the ink on the CFO certificate dries! Forced identity is a result of pure economic concerns of insensitive developers and government agencies that fail to place the priorities of the people in relation to the cultural interpretation of architecture. 


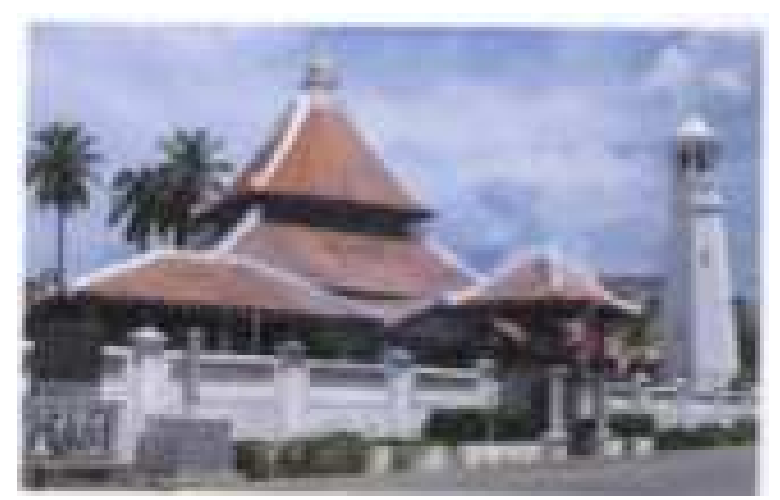

Fig. 13. Masjid $\mathrm{Kg}$ Hulu-Melaka

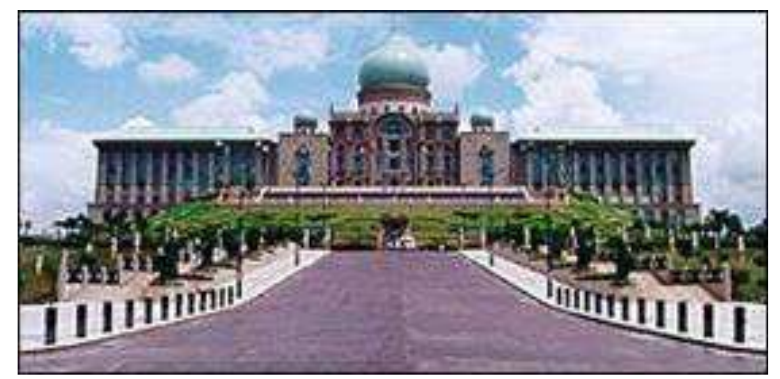

Fig. 14. Prime Minister Office, Putrajaya

\subsection{Manufactured Architectural Identity}

When politicians and professionals begin to impose their racial and political preferences, we have an architecture of manufactured identity. Most of the prestigious architectural works in the country fall into this category. On the one hand, this approach is valid from the perspective that a new nation with a multicultural people needs to select the so called universal traits and introduce new ones in order to develop a 'strand' that would propel the nation forward into a success story. On the other hand, manufactured architecture to suit political whims and fancies are a farce to the spirit of times and spirit of place that marks eons of 'good architecture'. In countries where the idea of democracy and good government are the more or less sole 'rights' of one party, manufactured architectural identity is a must as a political rallying cry. The next section deals with the various manufactured identity on architecture found in Malaysia (sample building shown at Fig. 14.

\section{APPROACHES IN MALAYSIAN ARCHITECTURAL IDENTITY}

We have classified five main approaches in architectural design that is primarily concerned with a Malaysian architectural identity. All of these approaches are born in many different ways from the mainstream movements and approaches of architecture in the west. Except for a few, most of the approaches such as revivalism, eclecticism and the use of metaphor have a superficiality that borders more on the populist notion of architecture. Though at first machine regionalism finds much promise of exploration in ideas, its sterile product finds not much place in a society strong in its traditions and religious belief. Only a few approaches possess the potential to seriously consider the issue of a national identity but there is not much discourse which emanate from its proponents. The huge potential of post-modern architecture as presented by Jencks and Graves have yet to find the light of day in Malaysia.

\subsection{Machine Regionalism}

This approach carries with it the tradition of Mies and Corbu in considering the building as nothing more than a machine that would sieve the climate through it. Corbu's brutalist architecture as shown in his Monastery La Tourette, Villa Shodan and Chandigarh inspired the Malaysian counterparts of Kuala Lumpur General Hospital and many of University Malaya lecture theaters, Convention Halls and office buildings and Ken Yeang's Roof-Roof house. The use of deep overhangs, 'egg crate' recessed windows, louvered shade and openings with exposed concrete construction characterized this architecture. Regionalists do not see themselves as looking for a specific national identity but merely to build a passive design shelter in response to the local climate. Some architects such as Ken Yeang carries this philosophy to such deconstructivist extremes as in the Mesiniaga in Subang Jaya (Fig. 15). Dr. Yeang's primary intention, it seems is to answer the question of a bioclimatic skyscraper in the tropics.

\subsection{Primitive Regionalism}

Primitive regionalism is similar in spirit to that of the machine regionalist in their quest for a climatically passive design building. However, the primitive regionalist believes that materials play an important role not only as something which would 
weather well but it connects man to his ancient origins as part of Nature's children. Frank Lloyd Wright can be said to be the father of an organic approach which saw the potential lessons of the past traditional architecture. In Malaysia, the resort architecture of Datai in Langkawi (Fig. 16), Sebana and Hotel Sofitel in Johor provides a tropical layout of verandahs, open buildings and lots of timber construction to suggest the fantasy of a tropical paradise. One problem with this approach is its questionable potential for public use if timber is its main character. Some believe that in order for this approach to join the big leagues of public architecture for an urban high density lifestyle the question of reinterpreting and innovating timber construction and air-conditioned less buildings would have to be seriously addressed.

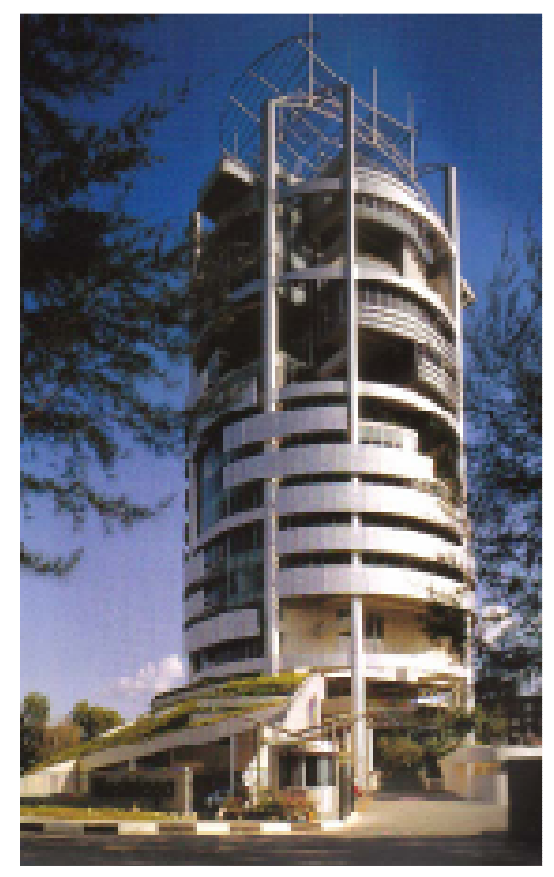

Fig. 15. Mesiniaga Building-Ken Yeang

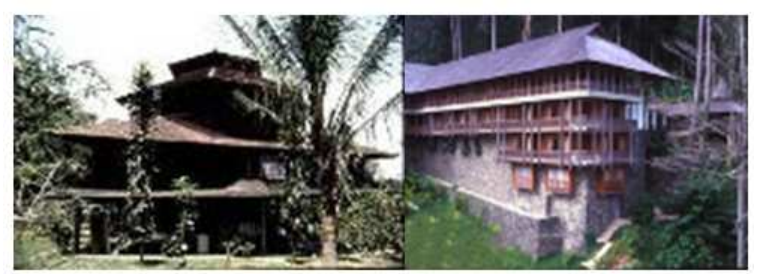

Fig. 16. Salinger House-Jimmy Lim, Datai-Langkawi

\subsection{Traditional Malay Revivalism}

One of the earliest responses to the government's call to project a national architectural identity was the proliferation of pseudo-traditional Malay architecture. Revivalism stems from such critics as Hassan Fathi who argues for a traditional vernacular revivalism to solve the problem of housing societies. However, many architects went astray from this honorable intention and embraced revivalism as what was practiced in Europe in the 18th and 19th century after the disasters with Mannerism and Baroque architecture. The Bank Bumiputra HQ was one of the first to answer this call and Convention Halls of PWTC (Fig. 17) was also in line with the spirit. The two buildings are highly charged symbols of the Malay political power and their populist response says much about the ruling elite. Buildings such as the Losong Museum which is supposed to cater for a more general audience seems to fall into the same quagmire. The three buildings follow a similar modus operandi which calls for the 'ballooning' of a traditional Malay residence into a gigantic structure of concrete. The main criticism of this particular type of architecture stems from the fact that the syntax of the traditional house fits best a domestic scale structure of timber and its transformation into a different building type suggest that the Malays may not possess high imagination and creativity. A similar revivalism tendency that swept England and America in the $18^{\text {th }}$ and 19th century saw critics like Louis Henry Sullivan attacking the inappropriateness of 'everything Roman and of totalitarian values' into an American bank of a democratic one. The National Museum in Kuala Lumpur seems to save the day with its honest attempt of arriving at a new vocabulary which saw the synthesis between classical monumentality and the sedate use of gable roofs and ornamentation. It may be argued that this approach may have taken the extension of the colonial stroke of synthesising European Classicism and the Malay vernacular. The Restoran Seri Melayu offers an interesting response to the problem of scale by breaking up much of the mass of the building thus retaining the humility of the Malay house but with a new function of a restaurant.

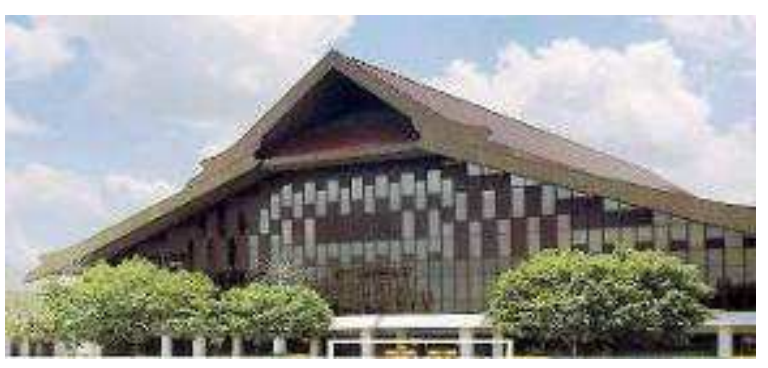

Fig. 17. Putra world trade centre 


\subsection{Metaphor}

The use of metaphors are identified with architects who view buildings not as mere shelters but as a totem pole riddled with messages. Although there were a few modernist who violated the cardinal rule of strict mechanical boxes, architects like Wright and Saarinen managed to get away quiet well with their own abstract rendition of flight as in the TWA Terminal and the praying hand as in the Madison Unitarian Church. Malaysian architects came out with their versions of metaphors as seen in such buildings as the Maybankkeris, the National Libraries romance with the tengkolok or Malay traditional male head dress, the National theater's sirihjunjung and the Telekom HQ 's pucukrebung (Fig. 18). The main attraction of this approach is again its populist appeal and the human weakness for novelty. Although the intention of these metaphors are serious in the eyes of the clients and the architects, one could not help but wonder how such vocabulary would fare with a new generation that no longer recognises these artifacts as primary symbols in their lives. Another criticism is about the reading of the metaphor. Charles Jencks suggest that the use of metaphors is better when one has to guess at its meaning rather than a direct reading. The abstract nature of Corbusier's Ronchamp, Wright's Unitarian Church, the Sydney Opera House and the TWA Terminal are testimonies to the potential strength of a suggestive metaphor.

\subsection{Modernistic Expressionism}

We have phrased the term modernistic expressionism to describe the National Mosque, the Parliament Building and the State Mosque of Negeri Sembilan. The term modernistic implies the machine approach of building as a climate sieve as in the works of Ken Yeang with a rejection of direct historical reference in its image. The term expressionism is used by historians and critics of architecture to describe a certain bent in modernist architects to use abstract metaphors which are almost always 'structuralized'. The Masjid Negara or the National Mosque is an excellent and unique creation of Malaysian architecture in that it frames the whole building as a huge wakaf-like shelter or as a generous serambiverandah structure. The building is horizontal in expression and this serves well the vocabulary of humility in Islam. The fact that the building is a tropical model with a lot of fenestration punctured by light-wells with ponds as inner courts add to the idea of moderation in the religion. The rejection of symmetry and a strict hiearchical composition of the massing presents well the image of Islam as a religion of the people rather than the poor middle-eastern imitation of domes, arches, courts and minarets common to the other mosques of its time and particularly of the present era. The mosque is an abstraction of the Malay house as evidenced in its raised prayer hall and serambi. The roof which covers the mosque proper or the prayer hall is a folded plate structure which is chosen because of its metaphor of a royal umbrella. The metaphor is seen as a reference to the mosque's uniqueness as the 'sultan' of all mosques in Malaysia and is meant only for this particular building. The Negeri Sembilan State Mosque is shaped with several intersecting conoids of reinforced concrete shell structure to refer perhaps to the curved Minangkabaugonjongroof forms. Thus, as in the folded plate roofs of Masjid Negara (Fig. 19), both buildings use metaphors that are integrated with the building structure. The Parliament Building (Fig. 19)presents two contrasting massing of a tower with suspended outer scales as sun shading device against a jagged pitched roof of reinforced concrete frame meant to refer to the high-pitched gable roofs of the Nusantara traditional architecture. The building presents a unique statement of democracy in Malaysia in its caution of not using any strong ethnic reference, its asymmetrical composition when seen from afar and finally its spartan image void of frivolous ornamentation.

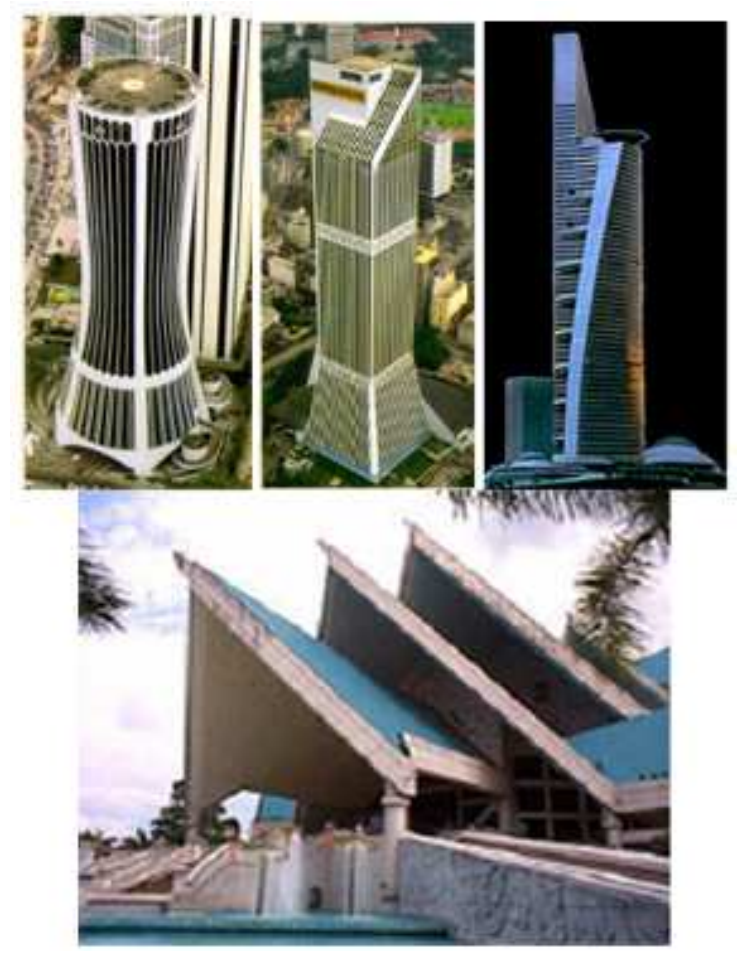

Fig. 18. Tabung Haji, Maybank, Menara Telekom and Balai Seni Lukis 


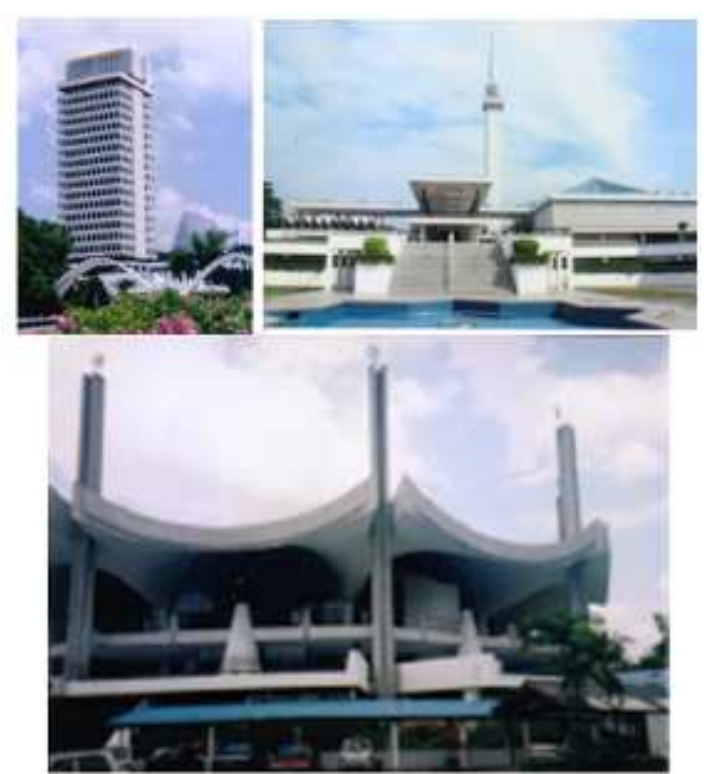

Fig. 19. Parliament Malaysia, National Mosque, Negeri Sembilan Mosque

\subsection{Eclectic and Ornamental Buildings}

Buildings in this category stems directly from the post-modern movement that unleashed a sense of raiding the historical past. Local architects were quick to capitalize on this approach without having much time to understand the background of the post-modern ideas. Most of the ornamental buildings in Malaysia do not attempt any position on national identity but was born primarily because of the idea for fun and fantasy. Many resort developments such as the Sofitel Hotel, Sebana and the Pulai Springs Club in Johor uses carvings at door panels in some of the main assembly rooms. The Sunway Pyramids (Fig. 20), the Palace of the Golden Horses and the Sunway Resort hotel which is the imitation of the Palace of the Lost City resort in Africa are buildings that are fully ornamental. The Putra Mosque, the Wilayah Mosque and the Shah Alam Mosques (Fig. 20) are those that are decorative in the way of using so called Islamic geometric patterns and calligraphy over their revivalistic and eclectic assemblage of domes and arches. The closest design consideration of ornamental identity are the Putrajaya lamp posts that litter the roads with its many different modern 'awanlarat' modes. Buildings such as the BSKL building, the Times Squere and others resort to meaningless circles and squares adorning the top of the buildings. The DayaBumi Complex with the Skudai Municipal Building both uses 'Islamic geometrical pattern work' as false curtain wall to perhaps identify it as an Islamic oriented architecture.

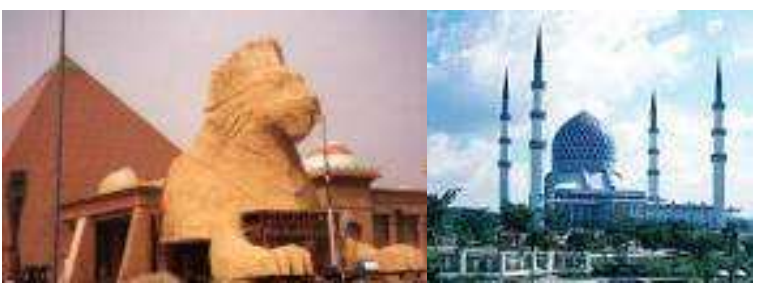

Fig. 20. Sunway Pyramide, Shah Alam Mosque

\section{REINTRODUCING THE 'SEMANGAT UKIRAN KAYU' IN CONTEMPORARY ARCHITECTURE IN MALAYSIA}

From the above deliberation, it can be seen that the idea of ornament had gone through many changes and development in the West. It can also be seen that in Malaysia there is very little development in the idea of ornament in Malaysia aside from the frivolous, simplistic pasting and dubious attempts as described in the previous section (Tajuddin, 2003). The problem of reintroducing the wood carvings in Malaysia must necessarily fall under the bigger question of ornament, meaning and architecture.

\subsection{Developing the Discourse}

In order to develop the discourse on ornament and architecture, we must be clear on the question of what is ornament, what is its purpose and what it was in the past. I choose to dwell with the question of the what is ornament first as a philosophical beginning rather than to its historical roots. Normally it is more important to start with the historical meanings rather than the philosophical musing (Utaberta and Mamamni, 2012a). However, we have always believed that reason must come first before embarking on any other research question.

We propose that the term ornament as used in the Western parlance was a product of modern historians who have undergone an outlook of life that are no longer religious (Utaberta and Sojak, 2012b). With the age of enlightenment, where the dogma of religion was replaced by the rationalism of science, the religious with its rituals and values were replaced with the animalistic idea of man as a biological entity in need of simple shelters just like bees or rabbits. Modern secular man saw no use for religious rituals like performing prayers and opted for a more intellectual and physical fitness program of life. Values of secularism relate not about doing good but to self propagation and survival only. In this respect, the Greek carvings that had religious meanings as well as the Gothic statues that had educational messages and also the calligraphic words of Allah are no more than 'any 
element that had no constructional or functional use'. Secularism does not recognizes solat as a necessary function because it is not part of the biological need for survival. However this view can be challenged by those who view man as a moral and spiritual creature with values and culture that would help create the most humane of human societies. Thus fasting, solat, pilgrimage and many other rituals actually perform the many biological, social and spiritual needs that would truly make man a complete human being. Thus, ornament of carvings and such help to remind man of certain religious messages as well as define the sense of space which one is in. We agree with the Post-modernist that a building is a totem pole of communication. We have to be able to 'read' a building in order to be able to function and be inspired in it.

Next comes the question of what ornament in Malaysia was in the sense of its meaning. There is very little work done to document and research the forms, placement and meanings of ornaments in our heritage buildings from houses to shops, mosques, palaces, temples and kongsi houses (Utaberta and Sojak, 2012b). We suspect that very few attempts have been made to research the meaning of ornament simply because no one saw its potential use as a tool of architectural communication but merely as a unnecessary beautifying element that has very restricted use then and now. We hope that many would now come forth to research the meanings of our traditional ornaments. Wesuspect that many of our traditional ornaments will show an intellectual and cultural integration between our diverse ethnic heritages. Would this finding not help the state of our racial harmony that now hangs in a dangerous imbalance? We would think that ornament would help tremendously the idea of a Malaysian identity that is not too parochially interpreted as a single ethnic expression.

\subsection{Transforming Ideas of Ornament towards Contemporary Relevance}

Practitioners of architecture and educators must first of all unlearn their idea that modern architecture had a single machine strand. They should study up on the architecture of Wright, Arts and Craft and Art Nouveau to familiarize themselves with some of the discussions on the role of ornament in architecture. Architects and educators must also re-look at their understanding of post-modern discourse on meaning and architectural form in order to rethink the idea of ornament as a simple applied form to a wall and transform it into three dimensional architectural elements.
Critics of this approach might point out that in one sense we would be subjecting traditional ornaments like wood carvings to an intellectual framework that is alien and thus any product of this forced identity might produce a low quality product. It may be possible to train new architects and designers by immersing them with the world views of traditional Malay and Chinese cultures and having them apprenticed to the master craftsmen but the logistic problems may be a factor. However, we support the idea of a small group of students and architect using this approach of apprenticeship to master craftsmen in order to preserve the heritage and pass it on as it was practiced for a long time. We are more of a strong supporter of the first approach where I find much relevance in using the western intellectual framework within the contexts of Malaysia's new political and social system. After all, architecture is not a piece of painting that sits in a museum isolated from the physical happenings of society. It must show relevance today and in the future. For instance, there is the question of motif in architecture. Of what relevance does the pucukrebung has as used in HijjasKesturi's Telekom Building, or the keris in the Maybank Building, the sirihjunjung in the Istana Budaya or even the tengkolok in the National Library. How many modern Malays would identify with such symbolism. What does it say about out democratic ethos of multiracialism? We need new motifs and thus new expressions to bring about a new Malaysia within the spirit of multiracialism and the spirit of the times.

\subsection{Timber Economics}

Finally, there is the pragmatic question of timber economics which has direct relevance to the 'semangatkayu' of traditional carvings. There are two problems that must be solved in order for timber to make a comeback in mainstream architecture. First is the question of permanence and second the question of export economics.

The question of permanence is a matter of attitude and not of technology. With the proper treatment and certain type of hardwood made commercially available, timber can last a long time as much as a century even for outdoor use. The JKR Police Barracks in Taiping and Butterworth uses timber as its outside wall panels on a four storey high rise family flats. The timber is still in excellent condition after almost half a century of use. The fire retarding quality of timber has been made longer by today's technology. There is also the added bonus that timber does not store heat like masonry and thus contribute to passive cooling strategy. I do not see why timber cannot be used extensively in 
buildings less than 10 storeys with the proper overhangs and shading devices. America is known to use a lot of timber not only for domestic architecture but also for auditorium halls and the like.

The second question is of pure economics. Malaysia exports her timber more than she uses them. The result is a material that is more expensive than any other. Timber is now an elitist element when once it was a popular material. Only hotels and resorts use timber to impress their clients with the fantasized idea of nature and organic integration. We do not have much expertise in the timber trading economics to offer any remedial suggestions. We only call upon those who do have the expertise to sit down with the architects and work out an idea of how timber as a sustainable and an eco friendly material can come back as a viable alternative building material.

\section{CONCLUSION}

We have attempted to illustrate how timber wood carvings in Malaysia has suffered the same fate of 'discontinuity' as other traditional carvings from the perspective of the discourse on ornament and architecture. The modern and post-modern discourse has been poorly understood in this region to the point that blind imitation of forms has led the way to our separating the traditional heritage into an architectural limbo. It is important at this juncture of history to look back not only of our responsibility at understanding and documenting our heritage but we also have a double responsibility of rethinking the western modern and post-modern discourse. It is only then that we might find the relevance that we seek in order to promote a more viable alternative to a meaningful Malaysian architecture. The semangatkayu of traditional wood carvings must evolve into shapes and ideas that must suit the spirit of the times in a dynamic country that has firm roots in the eternal values of culture.

As an attempt to give new breath to Malaysian Identity, we fully realize that this study is full of limitation as its main objective is to open a further discussion about Malay Wookcarvings within the framework of Architectural Identity. It is expected that more related research and discussion occurred as the basic problems of Malay woodcarvings has been requestioned. A deep study from the Tukang's (craftman's) point of view will be very important while other writings could discuss more on the connection of architecture and woodcarvings. The idea of architecture identity also need to be reframed as the culture and thought of Malaysian
People is rapidly changing under globalization and the shifting of tradition and custom.

\section{REFFERENCES}

Hassanpour, B., N. Utaberta and A. Zaharim, 2012. Necessity of tutor training in architecture education using Rasch measurement model. Am. J. Applied Sci., $\quad$ 9: $1884-1890 . \quad$ DOI: 10.3844/ajassp.2012.1884.1890

Corbusier, L., 1962. VersUne Architecture: Architecture of Pure Creation of the Mind. Colombia Universiti.

Curtis, W.J.R., 1996. Modern Architecture Since 1900. 3rd Edn., Phaidon Press, London, ISBN-10: 0714833568, pp: 736.

Jencks, C., 1977. The Language of Post-Modern Architecture. 1st Edn., Rizzoli International Publication Inc., New York.

Jencks, C., 1985. Towards a Symbolic Architecture: The Thematic House. 1st Edn., Rizzoli, New York, ISBN-10: 0847806596, pp: 248.

Pugin, A.W., 1977. The True Principles of Pointed Architecture. 1st Edn., Academy Editions, London.

Ruskin, J., 1925. The Seven Lamp of Architecture. 1st Edn., George Allen and Unwind Ltd., London.

Tajuddin, M.M.R., 1999. SeniBina di Malaysia: Kritikan Tentang Seni Bina Islam, Identiti Nasionaldan Pendidikan. 1st Edn., Design Modular Sdn Bhd., Selangor.

Tajuddin, M.M.R., 2001. Identiti Seni Bina Malaysia: Kritikan Terhadap Pendekatan Reka Bentuk. 1st Edn., Penerbit Universiti Teknologi Malaysia, Johor Bahru, ISBN-10: 983520215X, pp: 107.

Tajuddin, M.M.R., 2003. KALAM Papers: Housing Crisis in Malaysia: Back to a Humanistic Agenda. 1st Edn., Pusat Kajian Alam Bina Dunia Melayu (KALAM), Johor Bahru.

Utaberta, N. and H. Mamamni, 2012a. The study on the development of ornamentation in the architecture of safavid dynasty. J. World Acad. Sci. Eng. Technol., 67: 632-636.

Utaberta, N. and S.D.M. Sojak, 2012b. Typological study of traditional mosque ornamentation in Malaysia-Prospect of Traditional Ornament in Urban Mosque. J. World Acad. Sci. Eng. Technol., 67: 624-631.

Wright, F.L., 1958. The Living City. 1st Edn., Horizon Press, New York. 